\title{
Co-governance: A New Approach of North Sea Policy-making?
}

\author{
JULES HINSSEN* and JAN WILLEM VAN DER SCHANS $†$ \\ *Department of Policy and Management Sciences, University of Nijmegen, The Netherlands \\ $\dagger$ Department of Business Administration, Erasmus University Rotterdam, The Netherlands
}

In the case of a common pool resource such as the North Sea, environmental problem solving cannot be left entirely to national governments. Some problems can be solved only by including the local level, others require a global approach. Some responsibilities should be left to participants in the public shere, other responsibilities can be shared with participants in the private sphere. National governments must take into account their interdependency with other participants, a situation that has consequences for what is achievable and this determines the use of policy instruments and the organization of policies.

The organization and instrumentation of North Sea policies as has been developed by governments in the 1980 s seems to be insufficient to reach the targets set. The scale of environmental problems facing us today demands the development of new machinery, new policy instruments, and a new way of looking at the process of policy making itself. Can we expect national governments to do all the work alone, or should we look for a more central role for private participants such as user groups and environmental organizations?

In environmental problem solving the growing social, economic, and political interdependence between parties is evident. It is time to consider a form of steering which involves parties other than just national governments. We propose a co-governance approach which implies arrangements that are produced by and will be implemented through a network of participants involving both public and/or private sectors at the international, national, or local level (Godfroij \& Nelissen, 1993; Kooiman, 1993).

\section{Developments in North Sea Policies}

The 1980s were important for North Sea environmental co-operation for several reasons. In a crossnational review of environmental policies Weale (1992) shows that the anti-pollution strategy of the 'first green wave' (1970s) was in fact an approach with a strong emphasis on legal instruments. The main strategy in the 1980 s was to involve national politicians in solving environmental problems. This more political strategy of the $1980 \mathrm{~s}$ can be seen as a reaction to the failure of the strict legalistic approach of the 1970s.
For the North Sea area the anti-pollution strategy changed from an emphasis on international legal instruments (Treaty of Bonn, 1967; Convention of Oslo, 1972; Convention of Paris, 1974) to an emphasis on international political co-operation: the International Conferences on the Protection of the North Sea (ICNS) $(1984,1987,1990,1993)$. The change from one antipollution strategy to another is a matter of years. If we take for instance the first ICNS in Bremen in 1984, we find parties not yet able to develop a common understanding of principles such as the precautionary principle (Hinssen, 1993). Participants also did not agree on the actual level of pollution. It was only after these issues were resolved that firm goals on reduction of pollution could be set at the London (1987) and The Hague (1990) conferences. The most far-reaching goal was the $50-70 \%$ reduction of input of certain polluting substances via different pathways between 1985 and 1995 (Declarations of the London Conference par. XVI and The Hague, par. 2-including Annex 1a: list of priority hazardous substances).

Today we know that the objectives set at the London and The Hague Conferences will not be fully met. With hindsight we may conclude that reaching an agreement at the Conferences was probably more important than thoroughly considering ways to implement it: a case where the logic of politics overrules the logic of practical thinking? The debate at the intermediate conference in Copenhagen on the matter of performance is an illustration of the difficulties politicians and public opinion have with accepting failure. Admitting failure can give reserved countries an argument in future negotiations to slow down environmental policy making even more.

The ICNS are taking place against a general background of growing attention for the marine environment. The number of players participating in international forums has grown. One of the reasons for this development is the harmonization of activities within the ICNS and activities in other fields of water management, like the International Rhine Commission (Nollkaemper, 1990). For the North Sea this results in a growing number of national states participating in the policy making process (e.g. the participation of Switzerland). The policy making process has become 
more 'open'. In 1992 the non-governmental environmental organization Seas at Risk was admitted as an official participant in the preparations of the Conference. Further, the growing number of issues that existing forums have to cope with, have led to the restructuring of the North Sea policy arena. Recently, in 1992, the Oslo and Paris Convention were revised (Hey et al., 1993).

We conclude that North Sea policies, as being developed in the framework of International Conferences, have changed in several ways: on the level of content of policies (problem-definition, development of general principles) and on the level of organization (number and type of participants, links to other environmental/water areas). The question that follows is simple. Given these developments, will the political approach, as embodied in the International Conferences, be sufficient to bring about a sustainable use of the North Sea by the different user groups? Before we can answer this question two different ways of looking at the role of governments in the process of international co-operation will be discussed.

\section{Relation Between Government and Society: Pyramid or Network}

The legalistic approach in the 1970s assumed the existence of national participants with the capacity to implement international conventions on a national level. The approach is based on the image of national governments at the top of a pyramid and societal parties at the bottom of a hierarchically organized society. In this view governments can steer societal participants by a legalistic approach: the basis of the pyramid will react to the rules laid down by the top by simply obeying them.

This perception of the relation between government and society was quite common in the 1970s and also applied to North Sea policies. IJlstra (1986) states that no water-area in the world is better covered by rules than the North Sea. The question is whether these rules actually achieve what they were made for: a change in the behaviour of pollutors in order to improve the quality of the marine environment. Empirical studies show that this is not the case. Peet (1992) conducted a study on the application of MARPOL-rules regarding operational discharges from ships. He concluded that many Contracting Parties are not using all the appropriate and practical measures of detection, and that reporting of most parties is incomplete. In Pallemaerts' (1992) opinion the history of the ICNS shows that generating legal substance is not the strongest point of this forum.

In the network perspective governance is a process in which both governments and societal participants play an active role (Jordan \& Schubert, 1992; Van Waarden, 1992). Policies are being developed in and implemented through a set of public and private players which are each individually incapable but together form a network appropriate to perform the task. Public and private participants operate in the network, and by making choices they either reproduce the network or (partly) change it (e.g. by changing the constallation of participants). A network is not a stable, institutionalized structure, but reflects a process of constant development. It is a dynamic structure, not a static one.

In such dynamic situations involving multiple participants the instrumentation of policies need special attention. In 1992 the Dutch Scientific Advisory Board for Governmental Policies presented a report called 'Environmental policy, strategies, instruments and maintenance'. In the report three categories of steering were distinguished (WRR, 1992).

The first is steering by direct rules. This is a highly effective way of governing in situations when there are guarantees that the rules can be enforced. A classic example is the permit. One is allowed to fish at a pond when one has a fishing permit. The enforcement is effective: a law enforcement officer makes his round at the pond and asks the fishermen if they can show their permits. Violators are either sent away or booked.

The second is steering by negotiation. An example of this category is the covenant between the Port of Rotterdam and the German Chemical Industries (to be discussed below). Given the range of participants involved in the North Sea area, most policy processes are negotiated.

The third category of steering is called social governance. This manner of governing is so common, that we hardly define it as steering. Social governance is based on a commonly shared interpretation of what is desirable and what is acceptable. An example of this is politeness. To avoid constant conflicts in our daily interactions we have developed standards of behaviour. And if a conflict escalates, we have judges, who will steer by direct rules as discussed above. Common understanding between participants, a commonly shared frame of reference, can develop only in processes of reasonable argumentation and communication. 'Reasonable' in this case means a willingness to be prepared to propose and accept good reasons, rather than to rely on economic and/or bureaucratic power to win arguments (Van der Schans, 1993).

\section{Dredged Materials: An Illustration of a \\ Network (Based on Hinssen \& Goverde, 1993)}

The dredged material case provides an example of a growing interdependence between the local and the international level. In this case co-governing means a sharing of responsibilities between the national level of government (with the authority to make legally binding international agreements) and the local level of government (with a direct interest in reducing the level of toxic substance flowing in from upstream) and between public parties (with a political duty to preserve and/or improve water quality) and private parties (with the resources and expertise to invest in cleaner technology).

The Port of Rotterdam produces 23 million $\mathrm{m}^{3}$ dredged material annually. More than half of these 23 million $\mathrm{m}^{3}$ are polluted with heavy metals and chemical substances, carried by the river Rhine from the Ruhr area. The dredged material is stored in a large con- 
structed pit, outside Rotterdam, called the Slufter. This is necessary because dispersion at the North Sea is not allowed under international agreements made at the London and The Hague conferences. The storage capacity will suffice until 2002 . By then the dredged material coming down the river Rhine should have reached a level of environmental quality such that it can be dispersed at the North Sea. Since the municipal authorities of Rotterdam are also responsible for the Port of Rotterdam, and the costs of a new Slufter are high, they did not want to take the risk that international agreements will prove to be insufficient. If reduction targets negotiated by the national governments could not be reached by 2002 , the Rotterdam authorities would be unable to disperse the dredged materials. Thus they took the initiative and negotiated a 'covenant' (gentleman's-agreement) with the United German Chemical Industry. In the covenant the Rotterdam authorities agreed not to claim damages from the polluting industries, and from their side the industries agreed to invest in cleaner production technologies.

An interesting side effect of the Rotterdam initiative is that local and national governments make agreements with different contents, with the result that polluting industries are given (or create for themselves) opportunities to negotiate on different fronts. The covenant between the municipal authority of Rotterdam and the German Chemical Industry is an example of a local government acting on its own initiative, and by doing so actually influencing the position of national governments.

\section{Organization by Co-governance: Is it Possible?}

By their very nature common pool resources such as the North Sea involve a wide range of participants, both from the public and the private sector, both at the international, national, and local level. North Sea policies are influenced already by national governments as well as international forums such as OSPARCOM, ICNS, IMO, LDC, ICES, and the EC. Many of these organizations are linked by mutual representation in each other's organizations. For instance, the declarations of the North Sea Ministerial Conference are explicit about the relationship with OSPARCOM (Hayward, 1990).

We argue that making legally binding decisions without being able to enforce them is the wrong way forward. The development of North Sea policies would benefit from a common understanding among participants that national governments cannot be the only parties held entirely responsible for doing the job. User groups should take, and in an increasing number of cases in fact do take, co-responsibility not only for formulating North Sea policies but also for actually implementing them and enforcing them.

One example of co-governance is the surveillance system for ships entering the ports of some European countries. The innovation is that the responsibility for the implementation of IMO and ILO rules covering waste discharge, safety, and working conditions on board is not left entirely in the hands of the distant flag states but is shared with neighbouring receiving countries (Port State Control). In a Memorandum of Understanding an increasing number of European countries have agreed to inspect ships that enter their ports and to forbid them to leave the port if they fail to comply to the rules. A logical next step would be to grant more responsibility to local authorities in coastal areas and to port authorities to develop traffic control systems and establish safety standards which go beyond the compromise levels negotiated in the traditional international forums. The US government unilaterally established a more strict regime for ships entering US waters, the Oil Pollution Act of 1990, and this may be an inspiring example for Europe.

The recent change in the Dutch North Sea fishery policy provides another example of co-governance. The Dutch government is delegating some responsibility for quota management and enforcement to the fishery sector. Groups of fishermen have been formed which have agreed to a joint fishing plan to secure a stable supply of high quality fish. They have also agreed to sell the fish landed in the Netherlands at auction, and they can hold each other responsible in court for overfishing the group quota. In this way the government's international responsibility to control catch effort is supplemented by fishermen's responsibility to secure the long term profitability of the fishery sector. A logical next step would be to delegate the responsibility to negotiate the distribution of Total Allowable Catches to fishermen organizations at the European level.

There are also possibilities for co-governance in the field of offshore hydrocarbon mineral extraction. Due to the technological complexities and economic uncertainties multi-national oil companies co-operate intensively when they drill for oil or gas in the North Sea. Platforms are generally built by groups of companies, with one company operating as the operator responsible for day-to-day management of the platform. Environmental and safety standards are a common concern for the group of oil companies exploiting a platform, and the group may want to exclude those members that do not meet the high standards of performance agreed by the group. In this way a government policy of handing out, monitoring, and, if necessary, revoking drilling licenses can be supplemented by a group policy of monitoring among oil companies working together on the same platform. We do not have to look only to governments to punish the 'bad guys', we can expect something from the 'good guys' in the business as well.

Environmental organizations can also play a constructive role in North Sea policy-making. Last May the Dutch Working Group North Sea took the initiative in calling user groups together-they were asked to present a strategic view on their future use of the North Sea. It was the first time in the history of North Sea environmental co-operation that non-governmental organizations met, not to demand anything from national governments, but to try to find out what they could do together. Among others, there were delegations from the shipping industry (Intertanco), the fishing industry (the Dutch board of fish and fish- 
products), the offshore industry (NOGEPA) and recreational interests (Foundation Recreation). The feasibility of the various views was discussed by experts from different scholarly disciplines (ecology, economics, political science, international law). The seminar showed that user groups each had different perceptions of the problem. In some cases the user groups each used a different vocabulary and each conceived the role governments should play differently.

In our opinion, meetings like these contribute to developing a common understanding of the diversity and complexity of the problems and of the limited capacity of national governments to solve these problems all on their own.

\section{Conclusion}

There is a growing awareness, both among environmentalists as well as industrial user groups, that one should look not only to national governments to really solve the many problems that we are still facing in managing the North Sea in a sustainable way, but also seek direct interactions between environmental groups and industry user groups. This is not an easy road but it may well be the only road we can take.

Governments and societal parties are interdependent; this has consequences for what is achievable and for the use of policy instruments and the organization of policies. We have given some examples of co-operation between participants (public-public and privatepublic) in a network, in which direct rules are supplemented with negotiation and social steering, thus showing that this alternative for failing legalistic approaches is realistic. We believe that a common understanding between public and private parties at international, national, and local levels provides a basis for developing innovative North Sea policies that are more realistic, more legitimate, and ultimately also more effective.

Godfroij, A. J. A. \& Nelissen, N. J. M. (eds) (1993). Shifts in the Steering of Society, pp. 89-122. Coutinho, Muiderberg (in Dutch).

Hayward, P. (1990). The Oslo and Paris Commissions. In The North Sea: Perspectives on Regional Environmental Co-operation (D. Freestone \& T. IJlstra, eds), pp. 91-100. Graham \& Trotman, London.

Hey, E., IJlstra, T. \& Nollkaemper, A. (1993). The 1992 Paris Convention for the Protection of the Marine Environment of the North-East Atlantic: A Critical Analysis. Internat. J. Mar. Coast. Law $8(1), 1-75$.

Hinssen, J. P. P. (1993). Cooperation and Collective Policy Problems: on Shifts in North Sea Policies. In Shifts in the Steering of Society (A. J. A. Godfroij \& N. J. M. Nelissen, eds), pp. 89-122. Coutinho, Muiderberg (in Dutch).

Hinssen, J. \& Goverde, H. (1993). Dredged Materials in the North Sea: About Self-steering in a Policy Network. In Discussions on Physical Planning, pp. 199-208. Delft (in Dutch).

IJIstra, T. (1986). Enforcement of International Environmental Instruments in the North Sea: the missing link. In Reasons for Concern, Proceedings of the 2nd North Sea Seminar '86, Working Group North Sea Amsterdam (G. Peet, ed.), pp. 287-317.

Jordan, G. \& Schubert, K. (1992). A Preliminary Ordering of Policy Networks Labels. E. J. Polit. Res. 21, 7-27.

Kooiman, J. (ed.) (1993). Modern Governance, New governance-Society Interactions. Sage, London.

Nollkaemper, A. (1990). The Rhine Action Programme: A Turning point in the Protection of the North Sea? In The North Sea: Perspectives on Regional Environmental Co-operation (D. Freestone \& T. IJlstra, eds), pp. 123-138. Graham \& Trotman, London.

Pallemaerts, M. (1992). The North Sea Ministerial Declarations from Bremen to the Hague: Does the Process Generate any Substance? Internat. J. Mar. Coast. Law 7(1), 1-26.

Peet, G. (1992). Operational Discharges from Ships, an Evaluation of the Application of Discharge Provisions of the MARPOL Convention by its Contracting Parties. AID Environment, Amsterdam.

Scientific Advisory Board for Governmental Policies (WRR) (1992). Environmental policy, strategies, instruments and maintenance, SDU, The Hague (in Dutch).

Van der Schans, J. W. (1993). Governing in the face of diversity. In Research Paradigms in European Business Studies (T. Elfring \& H. Siggaard Jensen, eds). Proceedings of first EDAMA Summerschool.

Van Waarden, F. (1992). Dimensions and Types of Policy Networks. E. J. Polit. Res. 21, 29-52.

Weale, A. (1992). The New Politics of Pollution. Manchester University Press, Manchester. 